\title{
PROGNOSTIC SIGNIFICANCE OF SERUM VASCULAR ENDOTHELIAL GROWTH FACTOR-C (SERUM VEGF-C) AND LYMPH-VASCULAR SPACE INVASION IN EARLY STAGE CERVICAL CANCER
}

\author{
Heru Priyanto'), Andrijono²) \\ 1)Department of Obstetrics and Gynecology, Dr. Moewardi Hospital/ \\ Faculty of Medicine, Universitas Sebelas Maret \\ ${ }^{2}$ Department of Obstetrics and Gynecology, Dr. Cipto Mangunkusumo Hospital/ \\ Faculty of Medicine, Universitas Indonesia
}

\begin{abstract}
Background: Management of early stage cervical cancer is still challenging. Several clinical-pathological prognostic factors that are currently used in clinical practice include stage, bulky tumor, stromal deep invasion, differentiation, histology, lymph vascular space invasion and status of lymph-node. Serum Vascular Endothelial Growth Factor-C (VEGF-C) has an important role in metastasis as an angiogenic and lymphangiogenic factor. This study aimed to determine prognostic significance of serum VEGF-Cand lymph-vascular space invasionin early stage cervical cancer.
\end{abstract}

Subjects and Method: This was a case-control study conducted at January to October 2007. A sample of 47 early-stage cervical cancer patients including 14 patients with lymph node metastasis (case) and 33 patients without lymph node metastasis (control) was selected for this study. The dependent variable was lymph node metastasis. The independent variables were serum VEGF-C and lymph vascular space invasion. Serum VEGF-C levels were examined by ELISA method. The data were analyzed by logistic regression.

Results: A cut-off point of serum VEGF-C level of $10.07 \mathrm{pg} / \mathrm{mLresulted}$ in 78.57\% sensitivity and $96.97 \%$ specificity. The risk of lymph node metastasis increased with serum VEGF-C level $>10.07 \mathrm{pg} / \mathrm{mL}(\mathrm{OR}=80.0 ; 95 \% \mathrm{CI}=7.99$ to 800.71; $\mathrm{p}<0.001)$ and lymph vascular space invasion $(\mathrm{OR}=20.00 ; 95 \% \mathrm{CI}=2.32$ to $171.7 ; \mathrm{p}=0.006)$.

Conclusion: Serum VEGF-C and lymph vascular space invasion can be used as independent prognostic factor on the risk of lymph-node metastasis in early stage cervical cancer.

Keywords: cervical cancer, prognostic factor, serum VEGF-C, lymph node metastasis.

\section{Correspondence:}

Heru Priyanto. Department of Obstetrics and Gynecology, Dr. Moewardi Hospital/Faculty of Medicine, Universitas Sebelas Maret, Jl. Ir.Sutami No. 36 A, 57126, Surakarta, Central Java.

Mid-International Conference on Public Health, Best Western Premier Hotel, Solo, Indonesia, 18-19 April 2018 | 250 https://doi.org/10.26911/mid.icph.2018.05.12 